Natural Hazards and Earth System Sciences (2005) 5: 251-257

SRef-ID: 1684-9981/nhess/2005-5-251

European Geosciences Union

(C) 2005 Author(s). This work is licensed

under a Creative Commons License.

\title{
Evaluation of landslide susceptibility of Sete Cidades Volcano (S. Miguel Island, Azores)
}

\author{
A. Gomes, J. L. Gaspar, C. Goulart, and G. Queiroz \\ Centro de Vulcanologia e Avaliação de Riscos Geológicos, Universidade dos Açores, Rua Mãe de Deus, 9500-801 Ponta \\ Delgada, Portugal
}

Received: 2 November 2004 - Revised: 7 February 2005 - Accepted: 15 February 2005 - Published: 1 March 2005

\begin{abstract}
Sete Cidades is an active central volcano with a summit caldera located in the westernmost part of S. Miguel Island (Azores). Since the settlement of the Island, in the $15^{\text {th }}$ century, many landslide events occurred in this volcano, causing extensive damages in buildings and infrastructures. The study of historical records and the observation of new occurrences showed that landslides in the region have been triggered by heavy rainfall periods, earthquakes and erosion.

In order to assess landslide susceptibility at Sete Cidades Volcano, landslide scars and associated deposits were mapped through aerial photographs and field surveys. The obtained data were inserted in a GIS to produce a landslide distribution map. It was concluded that the high density landslide areas are related with (1) major scarp faults, (2) the margin of fluvial channels, (3) the sea cliffs and (4) volcanic landforms, namely the caldera wall. About $73 \%$ of the mapped events took place in areas where pyroclastic deposits are the dominant lithology and more than $77 \%$ occurred where slopes are equal or higher than $20^{\circ}$. These two parameters were integrated and used to generate a preliminary susceptibility map.

The incorporation of vulnerability data into the GIS allowed concluding that $30 \%$ of dwellings and most of the roads on Sete Cidades Volcano are located in areas where landslide susceptibility is high to very high. Such conclusion should be taken into account for emergency and land use planning.
\end{abstract}

\section{Introduction}

The Azores archipelago is formed by nine volcanic islands and is located in the Atlantic Ocean, between $37^{\circ}-40^{\circ} \mathrm{N}$ latitude and $25^{\circ}-31^{\circ} \mathrm{W}$ longitude (Fig. 1).

The geological setting of the Azores region is dominated by the existence of a mantle plume where the American,

Correspondence to: A. Gomes

(anagomes@notes.uac.pt)
Eurasian and African plates meet (White et al., 1979; Searle, 1980). The Mid-Atlantic Ridge and the Terceira Rift are the most important tectonic structures recognised in the area (Fig. 2), being the main source of the seismic and volcanic activity registered in the region (Machado, 1959; Weston, 1964). Since the settlement of the archipelago, in the $15^{\text {th }}$ century, many destructive earthquakes, volcanic eruptions and landslides were responsible for several deaths and substantial damage.

São Miguel, with about half of the Azores inhabitants, is the largest island of the archipelago and is located in the eastern part of the Terceira Rift. The island is formed by several volcanic edifices placed along a general $\mathrm{E}-\mathrm{W}$ direction and is crossed by NW-SE, NE-SW, WNW-ESE and E-W regional tectonic structures (Fig. 3). Sete Cidades Volcano is located in the westernmost part of S. Miguel occupying an area of about $110 \mathrm{~km}^{2}$. It is an active central volcano with a summit caldera and its eruptive history was marked by two distinct periods: the first one was dominated by the extrusion of lava flows forming the basal part of the volcanic edifice; the second, starting 36000 years ago, was characterised by the emplacement of major pyroclastic flows and tephra fall deposits.

\section{Historical accounts and recent events}

Since the settlement of the island many catastrophic landslides occurred at S. Miguel Island. The largest event was triggered by the $1522 \mathrm{AD}$ earthquake and destroyed the former capital of the Azores, Vila Franca do Campo, located in the south flank of Fogo Volcano, killing about 5000 people (Marques et al., 2004) ${ }^{1}$.

At Sete Cidades Volcano, the history reveals that landslides have also been the cause of extensive damages in buildings and infrastructures. The study of historical records and

\footnotetext{
${ }^{1}$ Marques, R., Gaspar, J. L. and Zêzere, J. L.: Reconstruction of the 1522 earthquake-induced landslide of Vila Franca do Campo (São Miguel Island, Azores), Eng. Geology, in revision, 2004.
} 
Table 1. Lithological classes and landslide density per $\mathrm{km}^{2}$.

\begin{tabular}{cccccc}
\hline $\begin{array}{c}\text { Lithological } \\
\text { class }\end{array}$ & $\begin{array}{c}\text { Outcropping } \\
\text { area }\left(\mathrm{km}^{2}\right)\end{array}$ & $\begin{array}{c}\text { Outcrop } \\
\text { area \% }\end{array}$ & $\begin{array}{c}\text { Number of } \\
\text { landslides }\end{array}$ & $\begin{array}{c}\text { \% of landslide } \\
\text { (over the total) }\end{array}$ & $\begin{array}{c}\text { Landslide } \\
\text { density per km }\end{array}$ \\
\hline L1 & 21,90 & 16,63 & 41 & 4,6 & 1,87 \\
L2 & 35,74 & 27,13 & 197 & 22,2 & 5,51 \\
L3 & 74,07 & 56,24 & 648 & 73,1 & 8,74 \\
\hline
\end{tabular}

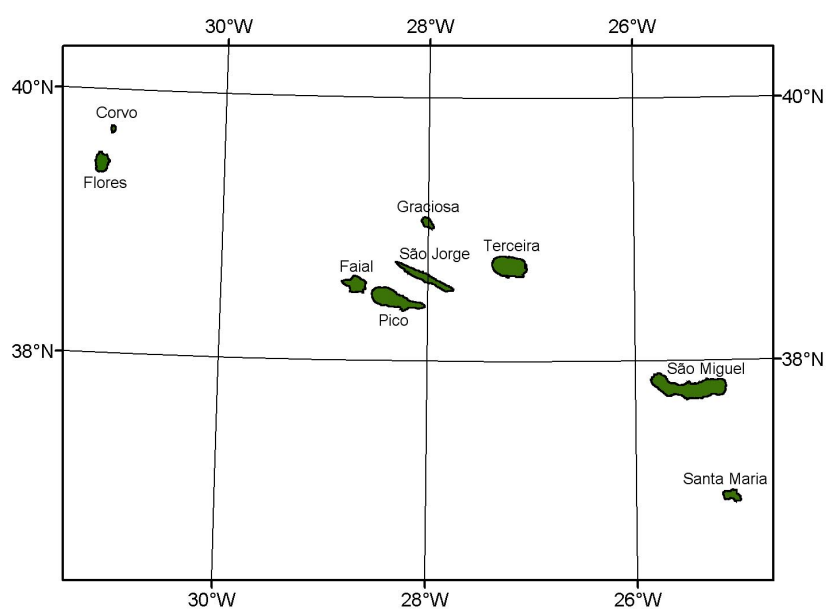

Fig. 1. Geographical location of the Azores archipelago.

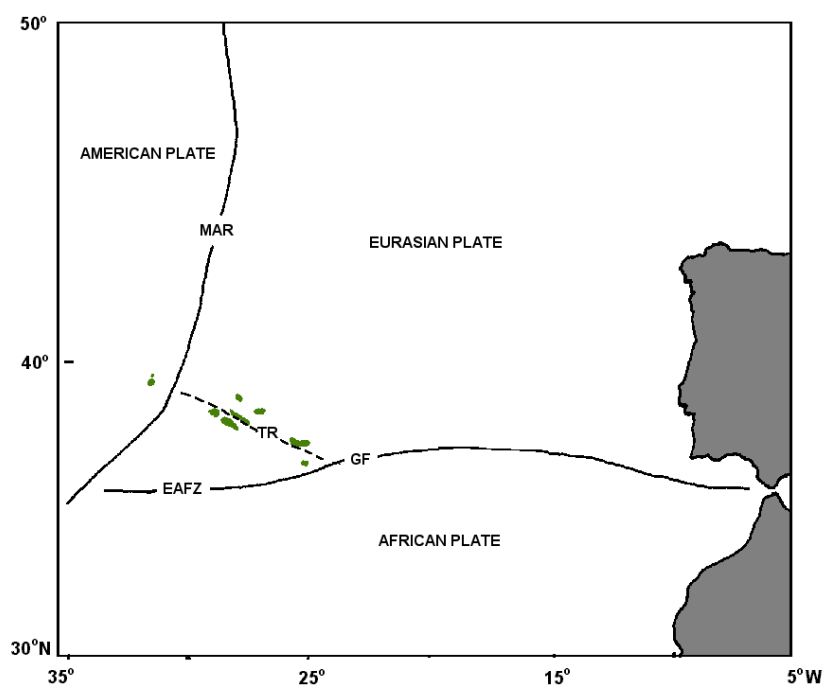

Fig. 2. Main tectonic structures in the Azores region. MAR - MidAtlantic Ridge; EAFZ - East Azores Fracture Zone; TR - Terceira Rift; GF - Gloria Fault (in: Gaspar et al., 1999).

the observation of new occurrences showed that heavy rainfall, earthquakes and erosion have triggered landslides in the region. On 8 December 1713, several landslides took place in the W flank of the volcano and important debris flows developed along some streamlines. Those events occurred associated to an intense seismic crisis that began on 14 November and lasted for about three weeks (e.g. Queiroz, 1997; Sil-

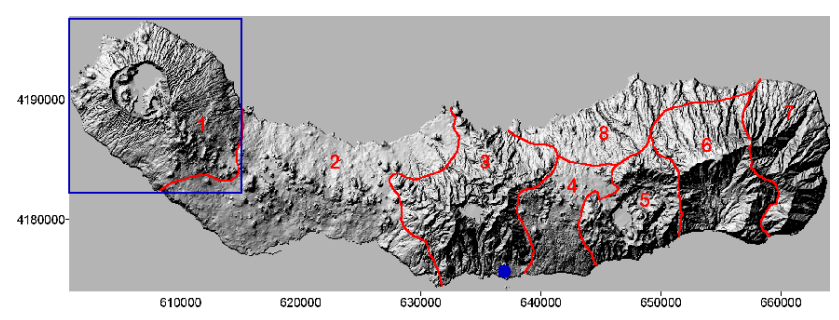

Fig. 3. Main morphological provinces of S. Miguel Island (Zbyszewski, 1961). 1 - Sete Cidades Volcano; 2 - Picos Volcanic System; 3 - Fogo Volcano; 4 - Achada das Furnas Volcanic System; 5 - Furnas Volcano; 6 - Povoação Volcano; 7 - Nordeste Volcanic Complex; 8 - North Platform (in: Wallenstein, 1999). $\square$ - Study area; blue $\bullet$ - Vila Franca do Campo, the former capital of Azores.

veira, 2002). No casualties were reported at the time. On 21 November 1988, landslides occurred following a 5.8 magnitude earthquake with epicentre $20 \mathrm{~km}$ west of the island. Most of the events were of debris flows type and cut the main roads around the volcano.

More recently, in January and February 2002, several landslides triggered by heavy rainfall associated with strong wind occurred in the SW flank of the volcano. At that time many dwellings were affected and roads cut (Malheiro and Dias, 2002) (Figs. 4 and 5). In February 2003, many landslides were observed in the NE sector of the volcano also triggered by an intense rainfall phenomenon (Fig. 6) and in October of the same year a road was cut in the $\mathrm{W}$ coast when a landslide occurred in the cliff as result of the normal coastal erosion process (Marques and Amaral, 2003) (Fig. 7).

In general, important landslides happen in Sete Cidades Volcano at least once a year, causing damages in dwellings, roads and other basic infrastructures.

Taking into account the idea that many landslides take place in zones already affected in the past (Carrara et al., 1995; Parise and Wasowski, 1999; Zêzere, 2001) and the principle that geological and geomorphological conditions verified in past landslides can be identical in futures events (Carrara et al., 1998), it is crucial to recognise the distribution of past landslides and to analyse the local factors that may have contributed to their occurrence. With the purpose to assess landslide susceptibility at Sete Cidades Volcano, three main parameters were considered at this stage: (1) the landslide distribution, (2) the lithology and (3) the slope steepness. 


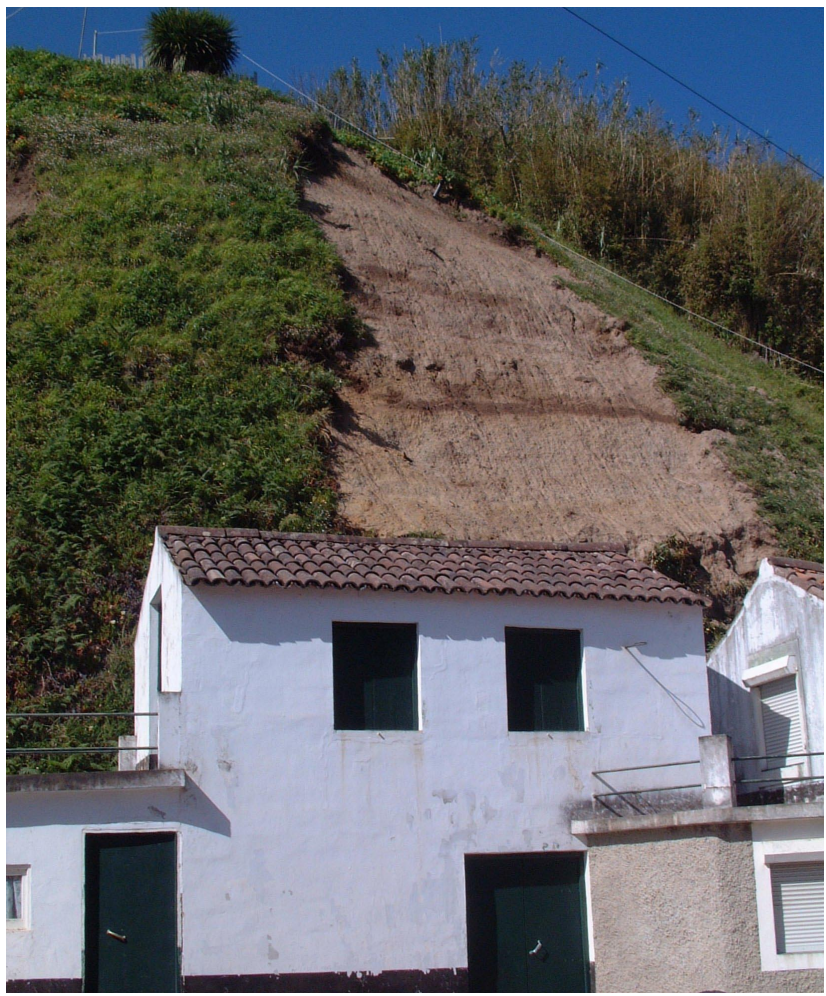

Fig. 4. Landslide scar generated during the January 2002 episode (Photo from CVARG).

\section{Landslide mapping}

Landslide scars, and when possible the associated deposits, were mapped using aerial photographs (1:8000 and 1:15000) from different years $(1974,1977,1982,1995$ and 1998) and several field surveys were conducted to characterise the most recent events. A total of 886 landslides were recognised, corresponding to more than $31 \%$ of the total events mapped in S. Miguel Island (Valadão et al., 2002).

The obtained data were introduced in a Geographic Information System (GIS) to produce the landslide distribution map presented in Fig. 8. The higher density landslide areas reveal a close relationship with the observed geological and geomorphological structures including (1) major scarp faults, (2) the margin of fluvial channels, (3) the sea cliffs and (4) volcanic landforms, namely the caldera wall and some cinder cones.

Specific evaluations of landslide susceptibility have shown specific differences between seismic and rainfall triggering events (Brabb, 1995). Unfortunately, except for the 2002 and 2003 recent events it was not possible to establish any relation between landslides and their trigger mechanisms.

\section{Lithological classes}

Three main classes of lithology were established for this study based in the S. Miguel Island Geological Map (Moore, 1991) and considering the vulcanostratigraphy of Sete

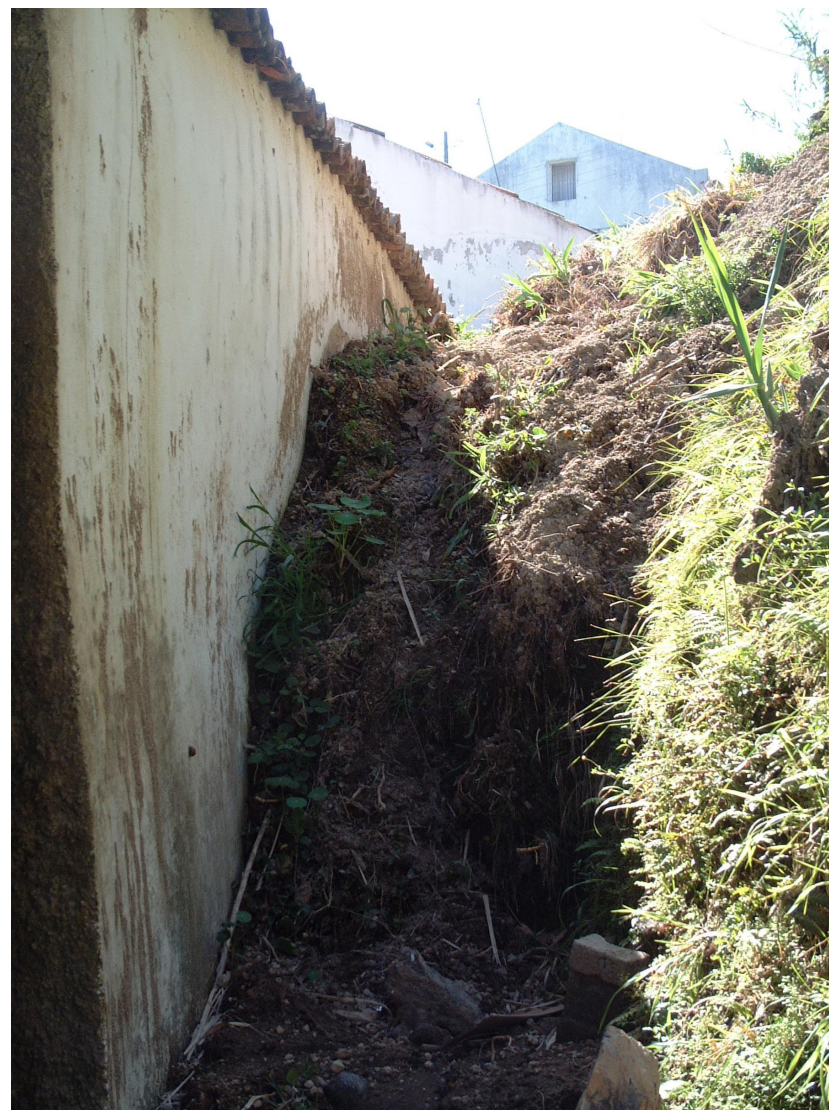

Fig. 5. January 2002 landslide deposit affecting the wall of a house (Photo from LREC).

Cidades Volcano (Queiroz, 1997): (1) class L1, essentially composed by lava flows; (2) class L2, characterized by both pyroclastic deposits and lava flows; and (3) class L3, where pyroclastic deposits are the dominant volcanic products.

The spatial distribution of such classes in the volcano region (Fig. 9) allowed to conclude that $56 \%$ of the area is generally covered by pyroclastic deposits while only $16,6 \%$ is composed by superimposed lava flows (Table 1). The analysis of the landslide distribution taking into account the lithology indicates that $73 \%$ of the events occurred in zones where pyroclasts are dominant and just 4,6\% took place in areas covered by lava flows. This difference persists when it is considered the landslide density per square kilometre (Table 1) and is due to the fact that the majority of the young pyroclastic products that cover the all area are of fall origin and form unconsolidated deposits that are more straightforwardly removed. This observation also explains why debris flows are the most common type of landslides that occur in Sete Cidades Volcano while rock fall events are restricted to the sea cliffs where lava flows are the dominant lithology.

\section{Slope steepness}

In order to study the relation between landslide distribution and slope steepness a digital elevation model was created 


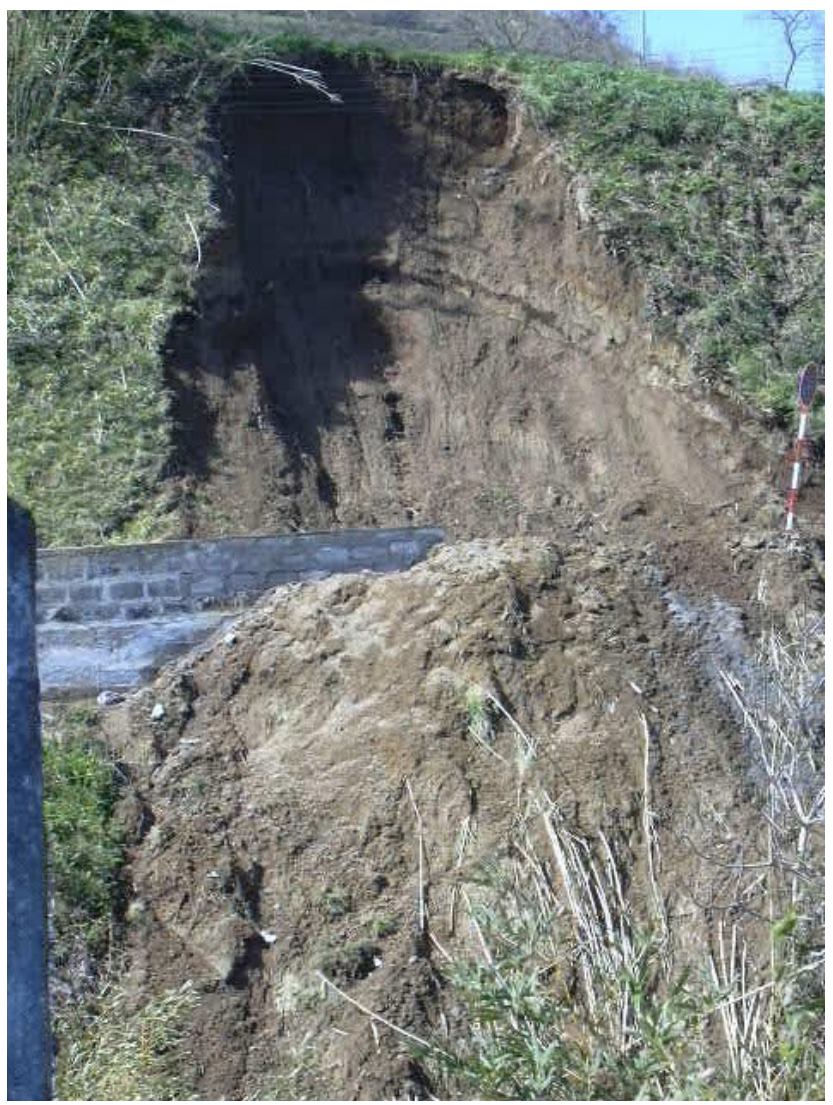

Fig. 6. Landslide scar and associated deposit formed in February 2003 (Photo from CVARG).

Table 2. Number and percentage of landslides vs. slope steepness classes.

\begin{tabular}{ccc}
\hline Slope steepness class $\left(^{\circ}\right)$ & Number of landslide & $\%$ of landslide \\
\hline $0-5$ & 27 & 3,0 \\
$5-15$ & 99 & 11,2 \\
$15-20$ & 73 & 8,4 \\
$20-30$ & 210 & 23,7 \\
$\geq 30$ & 477 & 53,8 \\
Total & 886 & 100 \\
\hline
\end{tabular}

Table 3. Weight given to the lithology classes.

\begin{tabular}{ccc}
\hline $\begin{array}{c}\text { Lithology } \\
\text { classes }\end{array}$ & $\begin{array}{c}\text { Landslide } \\
\text { susceptibility }\end{array}$ & Weight \\
\hline L1 & Very-low to low & 1 \\
L2 & Moderate & 2 \\
L3 & High to very-high & 3 \\
\hline
\end{tabular}

with the GIS ArcView ${ }^{\circledR} 3.3$ software using the elevation contour lines from the 2001 digital S. Miguel Military Map (Sheets 26, 27 and 31 in 1:25 000) published by the Instituto

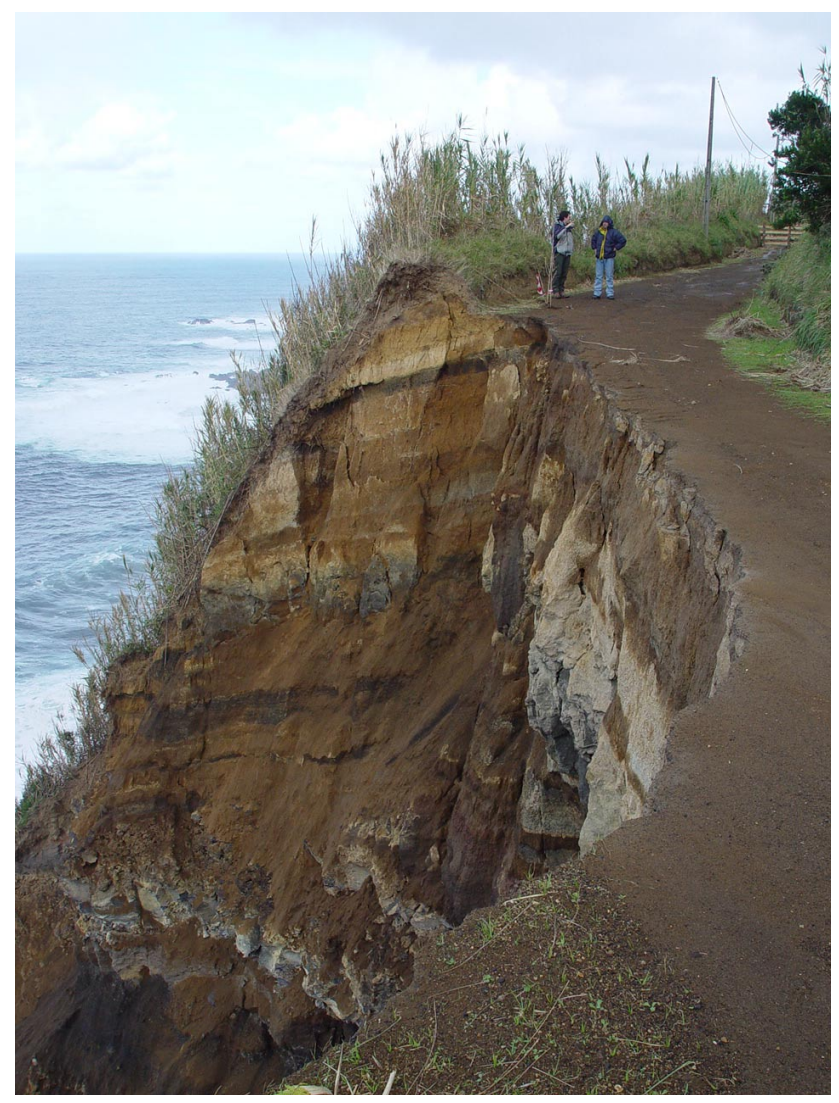

Fig. 7. Road cut in the NW coast of Sete Cidades Volcano as result of the October 2003 event (Photo from CVARG).

Table 4. Weight given to the slope steepness classes.

\begin{tabular}{ccc}
\hline $\begin{array}{c}\text { Slope steepness } \\
\text { class }\end{array}$ & $\begin{array}{c}\text { Landslide } \\
\text { susceptibility }\end{array}$ & Weight \\
\hline $0^{\circ}-15^{\circ}$ & Very-low to low & 1 \\
$15^{\circ}-20^{\circ}$ & Moderate & 2 \\
$\geq 20^{\circ}$ & High to very-high & 3 \\
\hline
\end{tabular}

Table 5. Number and percentage of dwellings in areas with different landslide susceptibility.

\begin{tabular}{ccc}
\hline Susceptibility & Number of dwellings & $\%$ of dwellings \\
\hline Very-low to low & 261 & 6 \\
Moderate & 2784 & 64 \\
High to very-high & 1305 & 30 \\
\hline
\end{tabular}

Geográfico do Exército. The automatic procedure provided by the GIS to produce the slopes map was first applied considering cells with $10 \mathrm{~m}$ width and class divisions every $5^{\circ}$.

The number of landslides falling in each class is presented in Fig. 10, showing a normal distribution with a maximum value in the slope class of $30^{\circ}-35^{\circ}$. Analysing the histogram 


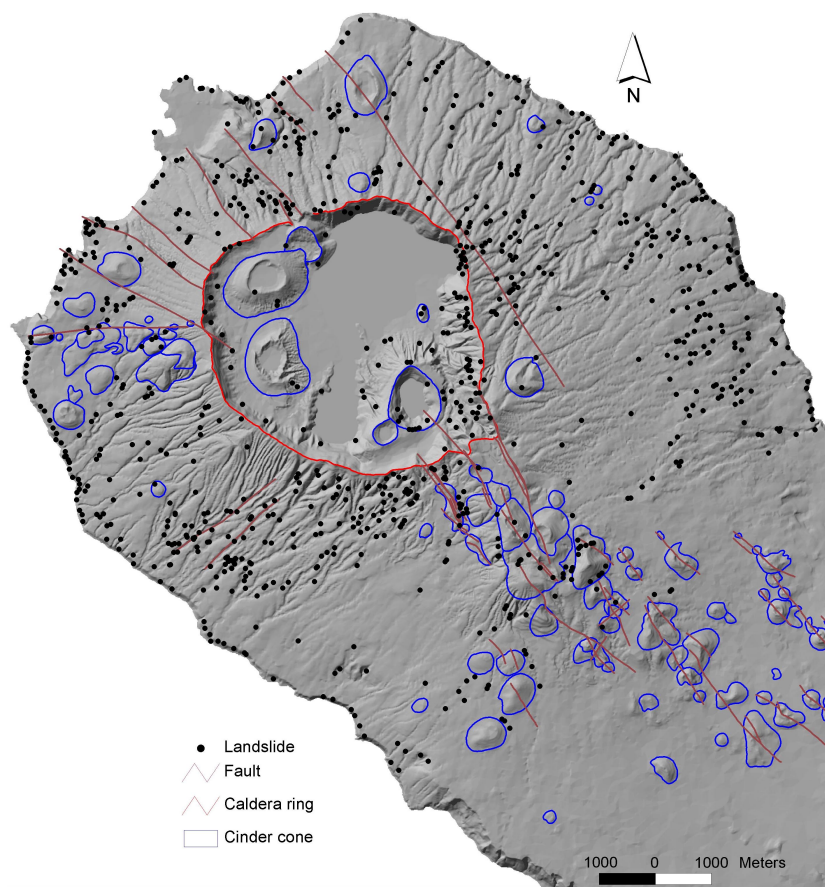

Fig. 8. Sete Cidades main volcano-tectonic structures (Queiroz, 1997) and landslide distribution.

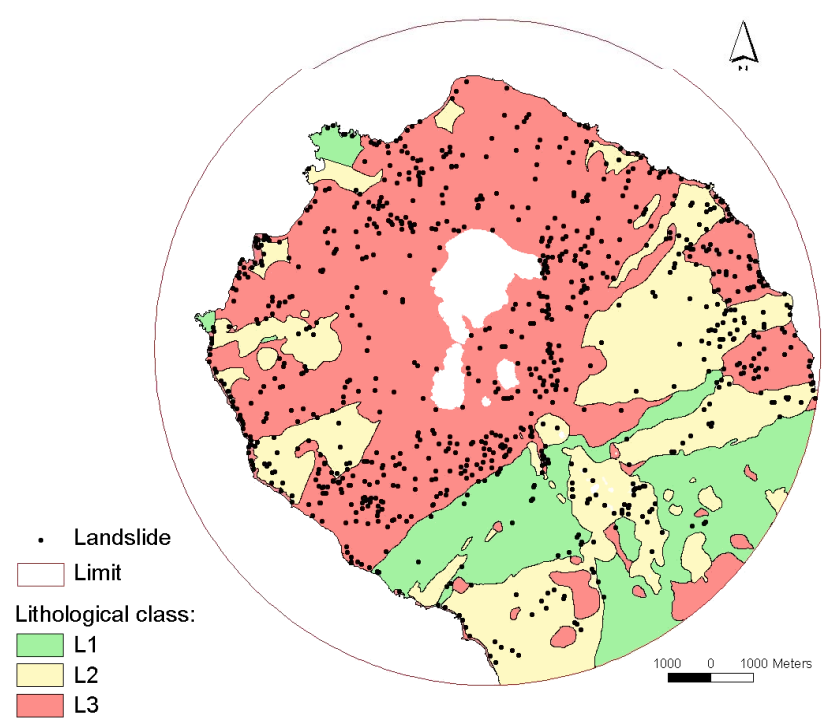

Fig. 9. Lithological map and landslide distribution. Legend: L1 Mainly lava flows; L2 - Lava flows covered and/or intercalated with pyroclastic deposits; L3 - Mainly pyroclastic deposits.

of Fig. 10 it emerged that five slope steepness intervals could be used to represent the data as it is proposed in Table 2 (e.g. Ruiz and Gijón, 1994; Zêzere, 2001). Based on such simplification a new slope steepness map was produced (Fig. 11). It was concluded that around $54 \%$ of the landslides occurred in slopes with steepness equal or higher than $30^{\circ}$ and more than $77 \%$ were located in zones where the inclination is equal or higher than $20^{\circ}$.

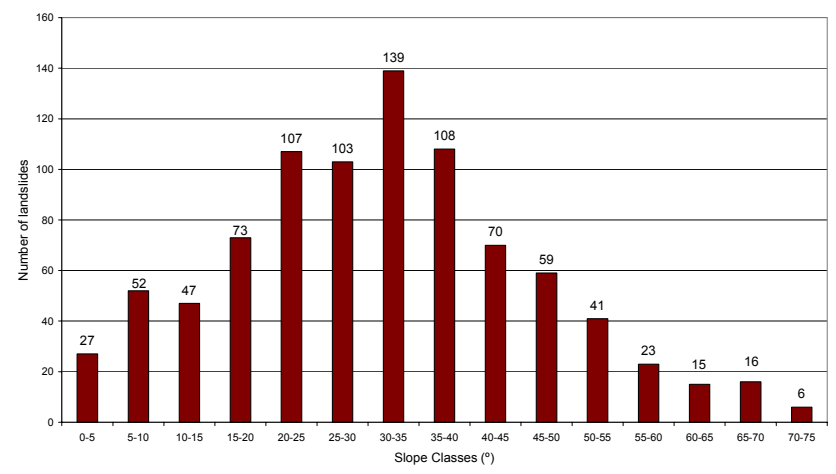

Fig. 10. Number of landslides in each considered slope steepness class.

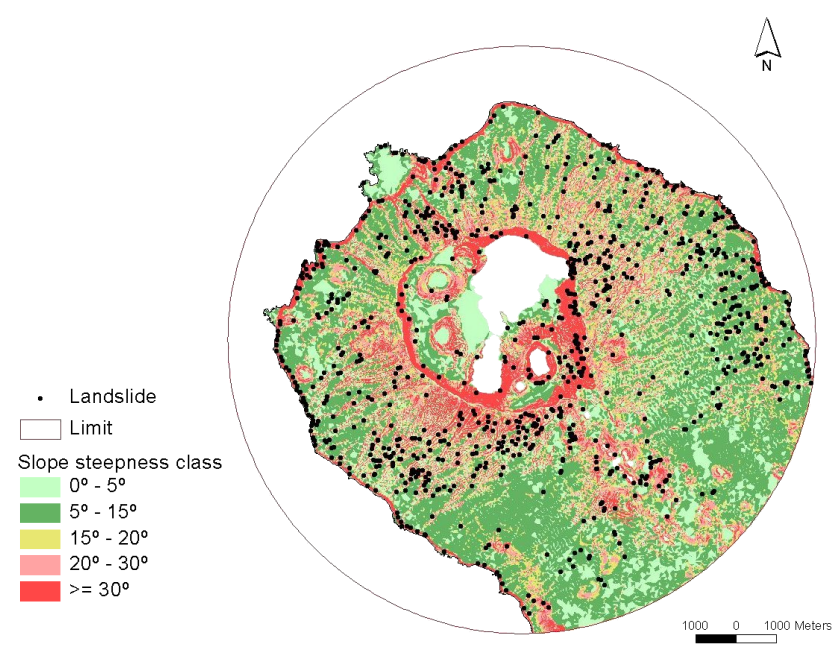

Fig. 11. Slope steepness map and landslide distribution.

\section{Discussion and conclusions}

The analysis of historical reports and the observation of recent landslide events that took place on Sete Cidades Volcano show that given a certain earthquake or rainfall episode, zones with different lithology or slope steepness behave differently. Debris flows are the most common type of landslides due to the fact that unconsolidated pyroclastic deposits formed during highly explosive volcanic eruptions covers all the area. Rock fall occur with major frequency in the sea cliffs where fractured lava flows from the volcano basement make the dominant lithology.

Based on this statement and taking into account the landslide distribution in the study area, relative weights were attributed to the considered classes of lithology (Table 3) and slope steepness (Table 4). The integration of such data in the GIS allowed to generate the susceptibility map presented in Fig. 12 and revealed that using such parameters landslide susceptibility is high to very-high in about $33 \%$ of the area, moderate in $53 \%$ and low to very-low in $14 \%$.

Sete Cidades Volcano is part of Ponta Delgada council and comprises ten parishes. According to the Census 2001, 


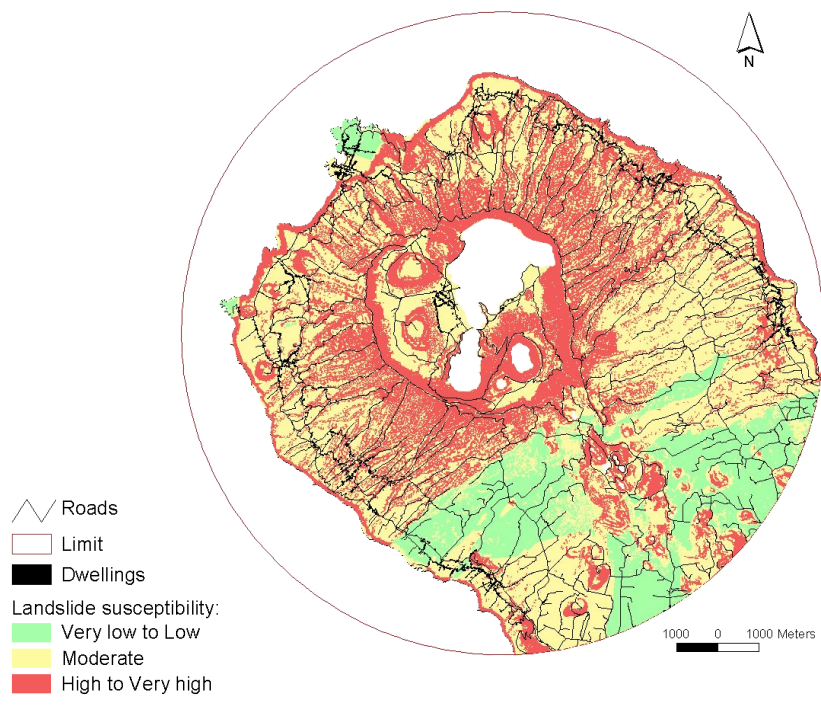

Fig. 12. Landslide susceptibility map and buildings distribution.

11429 peoples lives around the volcano. A detailed field survey allowed identifying 7019 buildings in the area, 4351 of which are dwellings (Gomes, 2003). The incorporation of the inhabited areas in the GIS (Fig. 12) show that 22\% (957) of the houses are placed in zones with high to very-high susceptibility and only 7\% (304) in areas of low to very-low susceptibility. The majority of the residences, $71 \%$ (3090) are located in areas of moderate susceptibility.

Bearing in mind that the rupture surface of a landslide develops behind the slope face it is clear that even flat terrains can be involved in such occurrences if adjacent to inclined planes. Field observations following the 1997 Ribeira Quente rainfall catastrophic event (Gaspar et al., 1997) and the 1998 Faial earthquake (Senos et al., 1998) allowed to verify that landslide rupture surfaces in zones with similar geology than the one observed at Sete Cidades Volcano occur frequently 5 to $10 \mathrm{~m}$ to the interior of the mobilized slopes. Assuming a buffer of $10 \mathrm{~m}$ behind the zones with higher steepness, namely the margin of valleys, the sea cliff, scarp faults and the caldera rim, it comes out that the number of dwellings in high to very-high landslide susceptibility zones increase to $30 \%$ (Table 5).

The simple methodology that was developed in this study for Sete Cidades Volcano emphasized that landslide risk analysis need to be taken into account concerning land use and emergency planning. Future efforts should consider the vulnerability of houses, basic infrastructures and economic factors.

Acknowledgements. This work was supported by Project CARIGE "Carta de Riscos Geológicos da Região Autónoma dos Açores", contact SRPCBA DIV 060402, and Project EXPLORIS “Explosive eruption risk and decision support for EU populations threatened by volcanos" contract PROID 095.

Edited by: P. Reichenbach

Reviewed by: M. Parise and G. F. Wieczorek

\section{References}

Brabb, E. E.: The San Mateo County California GIS project for predicting the consequences of hazardous geologic processes: Geographical Information Systems in Assessing Natural Hazards, edited by Carrara, A. and Guzzeti, F., Kluwer Academic Publishers, 299-334, 1995.

Carrara, A., Cardinali, M., Guzzetti, F., and Reichenbach, P.: GIS technology in mapping landslide hazard, Geographical Information Systems in Assessing Natural Hazards, 135-175, 1995.

Carrara, A., Guzzetti, F., Cardinali, M., and Reichenbach, P.: Current limitations in modelling landside hazard, in: Proceedings of IAMG'98, edited by: Buccianti, A., Nardi, G., and Potenza, R., 195-203, 1998.

Gaspar, J. L., Trota, A., Queiroz, G., Ferreira, T., and Alves, P.: Plano Municipal de Emergência da Vila do Porto, ilha de Santa Maria, Centro de Vulcanologia e Avaliação de Riscos Geológicos, Universidade dos Açores, 1999.

Gaspar, J. L., Wallenstein, N., Coutinho, R., Ferreira, T., Queiroz, G., Pacheco, J., Guest, J., Tryggvason, E., and Malheiro, A.: Considerações sobre a ocorrência dos movimentos de massa registados na madrugada de 31 de Outubro de 1997 na ilha de S. Miguel, Açores, Relatório Técnico-Científico 17/DGUA/97, Centro de Vulcanologia, 28, 1997.

Gomes, A.: Contribuição para o estudo dos riscos geológicos no Vulcão das Sete Cidades (S. Miguel, Açores), Tese de Mestrado em Vulcanologia e Riscos Geológicos, Universidade dos Açores, 129, 2003.

Machado, F.: Submarine pits of the Azores plateau, Bulletin Volcanologique, Série II, Tome XXI, 108-116, 1959.

Malheiro, A. and Dias, I.: Parecer sobre a segurança de sete moradias na Freguesia da Candelária, Nota técnica 51/2002, Laboratótio Regional de Engenharia Civil, 23, 2002.

Marques, R. and Amaral, P.: Avaliação do Risco geológico associado a um movimento de vertente na freguesia dos Mosteiros (ilha de S. Miguel), Relatório Técnico-Científico DTC 44/CVARG/03, Centro de Vulcanologia e Avaliação de Riscos Geológicos, 8, 2003.

Moore, R. B.: Geologic map of São Miguel, Azores, 1:50 000, U.S. Geological Survey Miscellaneous Investigations Series, Map I, 2007, 1991.

Parise, M. and Wasowski, J.: Landslide activity maps for landslide hazard evaluation: three case studies from Southern Italy, Natural Hazards, 20, 159-183, 1999.

Queiroz, G.: Vulcão das Sete Cidades (S. Miguel, Açores), História eruptiva e avaliação do hazard, Tese de Doutoramento no ramo de Geologia especialidade de Vulcanologia, Departamento de Geociências, Universidade dos Açores, 226, 1997.

Ruiz, R. and Gijón, M.: Methodology for landslides hazard map 1:10000 in the area of Monachil (Granada, Spain), 7th International IAEG Congress, 2059-2064, 1994.

Searle, R.: Tectonic pattern of the Azores spreading centre and triple junction, Earth Planet. Sci. Lett., 51, 415-434, 1980.

Senos, M. L., Gaspar, J. L., Cruz, J., Ferreira, T., Nunes, J. C., Pacheco, J., Alves, P., Queiroz, G., Dessai, P., Coutinho, R., Vales, D., and Carrilho, F.: O terramoto do Faial de 9 de Julho de 1998. Proceedings do "1 Simpósio de Metereologiae Geofísica da APMG”, 61-68, 1998.

Silveira, D.: Caracterização da sismicidade histórica da ilha de São Miguel com base na reinterpretação de dados de macrossísmica: contribuição para a avaliação do risco sísmico, Tese de Mestrado em Vulcanologia e Riscos Geológicos, Universidade dos Açores, 
149, 2002.

Valadão, P., Gaspar, J. L., Queiroz, G., and Ferreira, T.: Landslides density map of S. Miguel Island, Azores archipelago, Nat. Haz. Earth Sys. Sci., 2, 1-6, 2002,

SRef-ID: 1684-9981/nhess/2002-2-1.

Wallenstein, N.: Estudo da história recente do comportamento eruptivo do Vulcão do Fogo (S. Miguel, Açores). Avaliação preliminar do hazard, Tese de Doutoramento no ramo de Geologia especialidade de Vulcanologia, Departamento de Geociências, Universidade dos Açores, 266, 1999.

Weston, F.: List of recorded volcanic eruptions in the Azores with brief reports, Bol. Mus. Lab. Min. Geol. Fac. Ciências de Lisboa, 10, 1, 3-18, 1964.
White, M., Tapia, M. and Schilling, J.: The petrology and geochemistry of the Azores Islands, Contrib. Mineral. Petrol., 69, 201-213, 1979.

Zbyszewski, G.: Étude géologique de l'île de S. Miguel (Açores), Comunicações dos Serviços Geológicos de Portugal, tomo XLV, 79, 1961.

Zêzere, J. L.: Distribuição e ritmo dos movimentos de vertente na região a Norte de Lisboa, Centro de Estudos Geográficos, Área de Geografia Física e Ambiente, 167, 2001. 